\title{
The Mid-Victorian Revolution in Wesleyan Methodist Home Mission
}

by David Bebbington

University of Stirling

E-mail: d.w.bebbington@stir.ac.uk

The prevailing view of Victorian Methodism is unfavourable. Wesleyan Methodism, the second largest Protestant denomination in the United Kingdom, is thought to have played its part in the weakening of Christianity. Methodism, on the received narrative, remained down to around 1840 a vigorous movement, gathering in the working people of industrialising Britain. From that point, however, its onward progress in its predominant Wesleyan form was arrested by the rise of respectability, the dominance of rich laymen and the authoritarianism of its leadership under Jabez Bunting. The book that did most to establish this perspective was Kenneth Inglis' Churches and the Working Classes in Victorian England (1963). Inglis argued that, as cities burgeoned in the later nineteenth century, all the churches failed to adopt an effective way of reaching the mass of the population, but he took the Wesleyans as a prime example of a denomination that was beginning to succumb to the onset of secularisation. ${ }^{1}$ Twenty years later, in A History of the Methodist Church in Great Britain, Henry Rack, though offering some qualifications, accepted the broad lines of Inglis' interpretation. Figures that he cited seemed to confirm the analysis by showing that, although membership was rising in the Victorian era, population growth was outstripping it. Whereas in 1851 the proportion of the population in Wesleyan membership was 1.4 per cent, by 1901 it had dropped to 1.2 per cent. ${ }^{2}$ More recently, however, historians have shown that secularisation made far smaller inroads in the society of the later nineteenth century than had previously been supposed. In particular Callum Brown has contended that British values were shaped by Evangelical Christianity throughout the nineteenth century and long afterwards.

This article has been published in a revised form in Journal of Ecclesiastical History https://doi.org/10.1017/S0022046917001816. This version is free to view and download for private research and study only. Not for re-distribution, re-sale or use in derivative works. (C) Cambridge University Press 2017 
Far from being largely absent from worship, as Inglis proposed, the working classes flocked to church in the mid-Victorian years. Brown, who draws on the work of Clive Field on Methodism, has pointed out that the working classes formed a majority of most Victorian congregations. ${ }^{3}$ The pessimism of Inglis appears exaggerated or even misplaced. It is generally acknowledged that a more optimistic estimate of the success of the churches is in order.

The home missionary strategy of the Wesleyans calls for reassessment in the light of this fresh perspective on the effectiveness of the churches. Was Wesleyan Methodism adaptable during the years from the 1850s to around 1880? Inglis supposed that the broad answer was no. He contended that the structure of circuits and itinerancy inherited from John Wesley was tenaciously retained even though it was unsuited to the increasingly urban world of the period after mid-century. The circuit system, giving each Wesleyan minister responsibility for many chapels, meant that he entered most pulpits only rarely; and the itinerancy dictated that ministers in each circuit changed after only three years or even more frequently. Hence there was little bonding between minister and people. In the $1880 \mathrm{~s}$, however, Inglis points out that the Forward Movement in Wesleyanism grappled with the problem, calling for the erection in cities of central halls led by ministers who would address the social issues of the day. Crucially, the ministers were to appear regularly on the same platform and to hold long-term appointments, so breaking with the circuit and itinerancy principles. ${ }^{4}$ Christopher Oldstone-Moore has confirmed that Hugh Price Hughes, the leader of the Forward Movement, expounded a novel vision of a Methodist Church with national responsibilities, so fostering drastic innovation in his denomination's methods. ${ }^{5}$ Hughes, never short on bombast, described the foundation of his own London Mission as 'probably the most significant and important event in the modern history of Methodism' ${ }^{6}$ Consequently the mid-Victorian period before Hughes is generally perceived as lacking in innovation. Inglis does mention Charles Prest, the secretary of the committee responsible for home 
mission at this time, but claims that his techniques were not original, not successful, not large-scale, not designed for urban society and poorly financed. In short his work was 'not pioneering' and merely 'a token gesture'. ${ }^{7}$ Roger Standing, in a recent book on The Forward Movement, is similarly dismissive of Prest. ${ }^{8}$ That estimate, it is true, is not universally held. By contrast John Munsey Turner has written that Prest was 'a pioneer'. ${ }^{9}$ Yet there is a widespread sense that nothing much altered in Wesleyanism between Bunting and Hughes. Here the aim is to examine Prest's era more carefully and so explore whether Turner is right to diverge from Inglis. Was there a revolution in Wesleyan home mission before the 1880s?

Certainly a major precipitant of change was constituted by the Wesleyan reform crisis of 1849 to 1852 . Discontent with the domineering policies of Jabez Bunting and his circle found expression from 1844 onwards in the anonymous Fly Sheets and, when, in 1849, Bunting demanded that all ministers should sign a declaration denouncing the campaign of criticism, three of the alleged ringleaders were expelled. The result was an outburst of popular denunciation claiming that the rights of true-born Englishmen were being denied. In order to enforce reform, the radicals raised the cry of 'Stop the Supplies', refusing payment of their dues. Obtaining no redress, they haemorrhaged out of the Wesleyan body during the early 1850 s, the majority eventually emerging as the United Methodist Free Churches in 1857. ${ }^{10}$ During the five years at the peak of the reform crisis Wesleyan membership fell by some $100,000 .{ }^{11}$ Because circuits were expected to raise the bulk of the salaries of their ministers, a declining membership meant that many of them could afford to pay only lower sums and to employ only a smaller ministerial staff. Wesleyan ministers had the depressing experience of seeing congregations shrink and of having too little money for the support of their families and too few colleagues for the pastoring of their flocks. Morale in the ministry plummeted.

The loss of income to the parent denomination was catastrophic. In the spring of 1853 it was estimated that by the summer the four main funds of the denomination would together 
be in debt by as much as $£ 39,000 .{ }^{12}$ 'Our Connexional funds', one member of the finance sub-committee told a fellow-minister in April, 'are in a sad plight. ${ }^{, 13}$ Decisive action was required. For the short term, on the recommendation of the sub-committee, a Relief and Extension Fund was launched, eventually raising over $£ 82,000 .{ }^{14}$ But for the longer term, a more drastic rearrangement was called for. In 1853 the Contingent Fund, which existed to supplement circuit funds by, for example, topping up ministerial salaries, received $£ 1,680$ less than the $£ 10,800$ it had collected in $1846 .{ }^{15}$ It was Charles Prest who saw the way forward most clearly. He believed it was essential to lift the morale of ministers by increasing the income of those who were helped by the Contingent Fund and assisting circuits to pay extra ministers. To do that, however, more money was required. The raising of funds had to be yoked to the evangelistic imperative which was at the core of Methodism. If a fund could be branded so as to show that it was designed to spread the gospel, it might attract more and larger donations. Prest set out that vision in a series of letters to the denominational newspaper, The Watchman, showing how many parts of the country could benefit from an injection of fresh manpower. As a result, in 1856 the Contingent Fund was redesignated the Home Mission and Contingent Fund. With Prest as secretary, a full-time post from 1857, it became responsible not just for supporting existing circuit work but also for carrying the gospel into fresh places. The financial emergency precipitated by the reform crisis led to the creation of a major new agency promoting domestic church growth.

A second reason for the emergence of this institution, however, was the report on the Religious Census of 1851. In that year there took place the only official census of churchgoers ever conducted in the United Kingdom. Census officials required returns from every place of worship specifying the numbers present at each service. Because many people attended more than once, the figures obscure the totals of individual worshippers, but historians have recalculated the results so as to produce estimates of the actual number of attenders. The Wesleyans, according to the best appraisal, attracted some 924,000 people in 
England, which represented 5.46 per cent of the population. Overall the proportion of the population at church was approximately 39 per cent. ${ }^{16}$ While those statistics might today be considered extraordinarily good, at the time, when it was expected that all would be in church unless unavoidably absent, the numbers were thought appalling. The official report published three years later highlighted that members of the working classes were usually among the absentees. 'The myriads of our labouring population', remarked the writer of the report, were 'as ignorant as were the Saxons on Augustine's landing'. Prest was evidently much impressed by these findings. In the first annual report of the Home Mission and Contingent Fund in 1856, he quoted the sentence about the Saxons to support his contention that 'indifference to the claims and blessings of Christianity is the crying evil of our times' ${ }^{17}$ In his letters on home mission in The Watchman he reissued extracts from the census returns on public worship. ${ }^{18}$ The census evidently moulded Prest's way of thinking about the challenge of the unchurched. The Home Mission and Contingent Fund was his solution to the problem unearthed by the Religious Census.

A third motive for the creation of the fund was a desire to emulate the work already undertaken by other denominations. In the decade when Evangelical ascendancy in national life was more marked than before or since, co-operation with likeminded believers seemed natural. The agents of the Home Mission, declared Prest in 1860, were pursuing their work 'without unholy rivalry, and in cordial co-operation with the Evangelical activities of other Christians' ${ }^{19}$ Accordingly the exertions of the interdenominational London City Mission seemed exemplary. ${ }^{20}$ The existing Home Missionary Societies of the Independents and Baptists, the efforts of the Church of Scotland and the policies of the Free Church of Scotland were all worthy of imitation. ${ }^{21}$ Only the Primitive Methodists, who were said to have a few 'fluctuating societies, none of them considerable' in areas where Wesleyan home mission was called for, did not warrant being copied. ${ }^{22}$ Above all the Church of England had set a good example. At a time when Archbishop Sumner and Lord Shaftesbury, Evangelicals both, 
dominated the counsels of the established church, its growing efforts to provide for the nation spiritually commanded great respect. Prest quoted J. C. Miller, the Evangelical rector of St Martin's, Birmingham, in a letter to The Watchman; equally he cited with approval the Church Pastoral Aid Society, an Evangelical body, and even the Additional Curates Society, a High Church equivalent. ${ }^{23}$ Wesleyan Methodists ought not to fall behind. 'Methodism, too', wrote Prest in his first annual report, 'occupies, by the providence of God, a position of usefulness and influence in the country that cannot be overlooked or despised. ${ }^{24}$ The denomination must show that it was just as capable as the others, including the established church, of vigorous organised evangelism. The home mission venture was launched both because other denominations set a good example and because Wesleyans did not wish to be left behind.

The example of foreign missions was a fourth reason for the establishment of Prest's home mission. The Wesleyan Methodist Missionary Society, begun rather tentatively in 1813, had proved hugely successful in raising money. By 1846 contributions for foreign missions reached $£ 94,000$, nearly ten times the sum donated to the Contingent Fund, and, though the reform crisis sapped this enterprise like every other Wesleyan effort, $£ 78,000$ was still collected in $1851 .^{25}$ The spread of the gospel abroad was a popular cause. Wanting to replicate the financial achievements of the Missionary Society, Prest argued that home mission was as urgent as the overseas variety. Indeed, as he contended in his annual report for 1860 , in one sense it was more entitled to the generosity of donors:

It is a plain duty - to use our best exertions for the conversion of the Heathen abroad. May such exertions be increased! But the neglect of the spiritual claims of our countrymen, who minister to our wants, and by whose labour much of our capital and income has $[s i c]$ been obtained, involves a deeper responsibility. Those residing in our neighbourhood have the highest claim on our attention. ${ }^{26}$ 
As Prest's initial praise for overseas mission suggests, it is clear that many feared that the new scheme would divert funds away from the Missionary Society. The advocates of domestic mission had to point out that fresh converts at home meant more givers for gospel work abroad. Publicity was given to the news that, when a home missionary minister was stationed at Torpoint in Cornwall, the sum raised there for foreign missions increased fivefold. ${ }^{27}$ It helped that a strong supporter of Prest's scheme was William Arthur, once himself an overseas missionary and from 1851 a secretary of the Missionary Society, who coined the dictum that "every additional Minister and Church raised in Britain by home evangelisation becomes a new fountain of Missionary income, and a nursery for Foreign Missions' ${ }^{28}$ Yet the home mission had the same constituency as the overseas cause and it was an essential element in Prest's initial vision to imitate the chief money-raising technique of the Missionary Society, annual public meetings with star preachers from other circuits. ${ }^{29}$ Public meetings were duly held to enlist sympathies for the conversion of 'Home Heathenism'. ${ }^{30}$ Although the domestic version never attained the popularity of the overseas missionary meetings, they were an indication that home missions planned to imitate the accomplishments of the foreign cause.

The consequence of these factors - the reform crisis, the census report, the example of others and the precedent of foreign work - was the setting up, under the auspices of the Home Mission and Contingent Fund, of a new category of 'home missionary ministers'. Special regulations to govern their activities were drawn up in 1858. The fundamental principle was that such men were not to be absorbed in the regular working of circuits. They were assigned separate districts and required not to deputise for ordinary circuit ministers. Each, according to the regulations, must 'give himself wholly to his distinctive and proper work'. His calling was essentially to visit from home to home, 'taking care to go to every house to which he can gain access, until all have been visited'. He should initiate spiritual conversation, distribute tracts, encourage school attendance and invite to special religious services, which should be 
'extemporized and informal'. ${ }^{31}$ He must keep a careful journal, such as was required of overseas missionaries, and complete an annual report. The circuit was normally to share the cost roughly evenly with the central fund. At first the ministers employed in this work were young, unmarried men, but from 1862 the preference was for older men with families. ${ }^{32}$ There were other changes. By 1876 a missionary minister reported that, since he was responsible for a church of over 180 members, pastoral visitation took up a great deal of his time. ${ }^{33}$ Clearly he had been absorbed into the regular life of the circuit far more than had been envisaged at the start of the scheme. In the following year it was explained that in Horncastle, Lincolnshire, the town was too small to create a separate mission district and so 'the work of the Home-Missionary Minister is, to a great extent, unavoidably blended with that of the other Circuit Ministers' ${ }^{34}$ Over time, then, the missionary ministers became less distinct. But they did prove a success. Numbers grew from an initial 4 in 1857 to 33 by 1860 and 83 by 1865. At that point shortage of money dictated a decrease, but from 82 in 1872 numbers again expanded to 106 in $1875 .{ }^{35}$ By 1863 the total amount the committee was paying missionary ministers had risen to become almost as high as the amount it spent on helping poor circuits. ${ }^{36}$ It was generally agreed that the home missionary ministers did provide the shock troops for the aggressive evangelism that the age required.

How much of a novelty did they represent? In several respects the pattern was traditional. The calling of the home missionary ministers virtually echoed John Wesley's advice to his assistants at the 1766 Conference to 'Go to each house' providing 'suitable exhortation and direction'. ${ }^{37}$ The message of the new appointees in particular was not to contain novelty. In the mid-Victorian development there was no change in theology equivalent to the emergence of a social gospel in the later Forward Movement. The normal Evangelical priorities were emphasised. The regulations required that missionary ministers should 'introduce as much of the Scriptures as possible in conversation' and engage in 'the simple and faithful preaching of Christ crucified'. They were to show zeal for 'the salvation 
of their perishing countrymen' and their very existence was testimony to the need for relentless activity. ${ }^{38}$ They therefore displayed the four qualities that have been seen as the hallmarks of Evangelicalism: biblicism, crucicentrism, conversionism and activism. ${ }^{39}$ 'We want no new schools for this work', declared the 1861 annual report; 'we want nothing but the old paths of our Fathers; we want nothing but the old Gospel'. ${ }^{40}$ Samuel Waddy, governor of Wesley College, Sheffield, a close friend of Prest and a member of the committee of management of the Home Mission from 1862, used to tell his family that the first principle of Methodism was 'That the Gospel is the only and all-sufficient means, Divinely appointed, for insuring the welfare of mankind' ${ }^{41}$ The home missionary ministers entirely concurred in that view. There was no element of innovation in the theology they professed.

Likewise the home missionary scheme did not challenge the existing organisation of Wesleyan Methodism. In the wake of the reform controversies there was no question of introducing significant institutional change. It is not surprising, therefore, that the new system slotted carefully into the current structures. The regulations specified that the home missionary ministers were to be subordinate to the superintendent ministers of their circuits, and that the work, 'in common with our other proceedings in Circuits, will be under the supervision of the District Committees'. The enterprise must avoid the risk of 'interfering with or contravening any of the principles of our providentially-formed and well-tried discipline'. Hence the missionary ministers, for all their distinctive work, were not to have a separate status. To set them apart would be 'fraught with evil consequences to the unity of our Body and to the harmony and efficiency of its action'. ${ }^{42}$ Accordingly Prest was always scrupulous to call his agents not 'home missionaries' but 'home missionary ministers', men no different from their peers in ordinary circuit work. From 1862 onwards, furthermore, the aim of the missionary ministers was to create so effective a system of evangelism that their districts could be incorporated in the general work of the circuit. ${ }^{43}$ Local home mission 
arrangements, that is to say, should eventually blend entirely into the existing structures. There was no intention of institutional revolution.

Again, there was a continuing reliance on rich patrons. Just as under Bunting, prosperous laymen did much to fund developments and so exercised a high degree of influence over them. The management committee of the Home Mission and Contingent Fund, apart from connexional officers, consisted of between eight and a dozen of each of four groups: ministers from the London area, ministers from the rest of the country, laymen from London and laymen from elsewhere. The committee met rarely, usually leaving affairs to the secretaries with Prest at their head, but the lay representatives, especially those from the capital, were normally men of standing whose opinions had to be treated with respect. At first Thomas Farmer, a chemical manufacturer who lived in Hammersmith, exerted a powerful influence until his death in 1861 , when he left a legacy of $£ 250$ to the fund. ${ }^{44}$ Subsequently the weightiest layman was Francis Lycett of Highbury, a glove-maker who rose to be sheriff of London in 1866 and received a knighthood in the following year. At that point he retired to devote himself to philanthropy, in which the erection of Methodist chapels and schoolrooms loomed large. Sir Francis regularly laid foundation stones up and down the country, and in 1870 offered the vast sum of $£ 50,000$ for fifty new chapels. ${ }^{45}$ He was willing to express decided views. 'Look again at the Mile End', he wrote in a private letter of 1872, 'the Home Miss[ionar]y there does nothing and is totally unfitted for the position nor is the man at Paddington much better - I feel we are doing Methodism great harm by sending such juveniles into London where we need some of the best men that God has given us' ${ }^{46}$ Another layman, this time unnamed, was said in 1868 to have donated $£ 1,500$ towards a building in Bethnal Green, but in future was disposed to give, not to large chapels, but instead to school-chapels and schools. ${ }^{47}$ That guidance, which was largely followed, would have been hard to resist. Wealthy laymen played as large a part in framing Wesleyan policies, 
including on home mission, as they had done in the age of Bunting. The role of such men was another aspect of continuity with earlier days.

Yet there were also marked novelties in the mid-Victorian home missionary programme. For one thing, it paid special attention to urban Britain. Efforts were lavished on London in particular. The capital had not been a denominational strongpoint, the Wesleyan Methodists at the 1851 census having only a small proportion (5.2 per cent) of church attenders there, by comparison, for instance, with the high figure (25.2 per cent) for Leeds. ${ }^{48}$ Accordingly, from the start of the home mission, the largest district financial allocation was to London. ${ }^{49}$ In 187114 out of 78 home missionaries were deployed in the capital. ${ }^{50} \mathrm{~A}$ parallel scheme, focusing on buildings rather than preachers, ran from 1861. This highly successful venture, initiated by William Arthur, was the Metropolitan Chapel Building Fund, to which Lycett gave generously. Repeatedly, and especially after, in 1866, policy changed to allow funding of chapels seating fewer than 1,000, places where home missionary ministers served had buildings erected by the Metropolitan Fund. ${ }^{51}$ Although there were requests from rural areas for agents of the home mission, Prest's report for 1861 commented, 'the most urgent demand is from the Metropolis' ${ }^{52}$ The most energetic efforts at this time were made by Alexander M'Aulay, later Charles Prest's successor as secretary of the Home Mission and Contingent Fund, who from 1858 to 1861 was stationed in Poplar. At the end of his term, he requested to be located in the adjacent area outside the metropolitan boundary in Bow and Plaistow Marsh, where the expansion of the London Docks had suddenly created a vast population. He became superintendent of a new home missionary circuit, the Twelfth London, and within two years established ten society classes, the weekly groups that formed the core of Methodism. ${ }^{53}$ By 1868 the Bow Road Chapel was an extraordinary beehive of activity. There were a Sunday school, a day school, a home missionary society and a juvenile home and foreign missionary society. There were also a Bible woman, a domestic mission, a mothers' meeting, a maternal society, a Dorcas society, a tract society, a Sabbath school for 
adults, Sabbath Bible classes for young men and young women, a young men's association, a home and foreign missionary library, a congregational library, a school library, a penny bank and a ragged school in course of formation. ${ }^{54}$ Here, long before the Forward Movement, was a range of facilities similar (though not identical, because of the different circumstances of the time) to those the movement was to advocate. The social as well as the religious needs of outcast London were being addressed.

In other urban areas there was extensive home missionary outreach. Nine of the sixteen appointments in 1859 , for example, were to town or city circuits. ${ }^{55}$ Expanding towns on the coast were discussed by the Home Mission Committee and then catered for by a special Watering Places Fund that was proposed by William Morley Punshon and largely financed through his lecturing efforts. ${ }^{56}$ The urban enterprise that turned out to be most significant, however, was in Liverpool. There a chapel in Pitt Street near the city centre was chosen as the base of operations for a home missionary minister in $1861 .{ }^{57}$ The missionary managed to organise cottage prayer meetings, Sunday evening services and open-air preaching that attracted a multitude of sailors. A Sunday school flourished, a penny bank opened and tract distribution went ahead. In March 1862 there were eighty-six members on trial, an indication of evangelistic effectiveness. ${ }^{58}$ The success, however, did not endure. By 1874 the missionary then serving had become despondent. 'The neighbourhood has greatly deteriorated', he reported, 'the congregations are small, and the surrounding wickedness great. ${ }^{, 59}$ In the following year, that decay provided the opportunity to turn Pitt Street into a mission of a more elaborate type. Its creator was Charles Garrett, an immensely popular minister who had begun another mission, locally funded and staffed by laypeople, in Manchester in 1872, just before leaving for Liverpool, where he served under Alexander M'Aulay in the Cranmer Chapel circuit. The two men may well have plotted together a new approach, but the precipitating factor was the Liverpool mission by the American revivalists Dwight L. Moody and Ira D. Sankey in 1875. Garrett, a keen temperance reformer, outlined a 
scheme for establishing a series of cocoa taverns to keep Liverpudlians off the bottle; Moody persuaded the wealthy Presbyterian merchant who sponsored his campaign, Alexander Balfour, to endorse the scheme; and Balfour insisted that Garrett should remain long-term in Liverpool to manage it, thus breaking the itinerancy principle. ${ }^{60}$ Garrett was put in charge at Pitt Street, which was financed by Balfour and his friends as the Liverpool Mission, and set about establishing not only cocoa taverns (of which eventually there were over seventy) but also lay-led mission halls scattered about the area. ${ }^{61}$ Garrett remained until 1899, setting a precedent for some of the features of the Forward Movement, though not its characteristic Central Halls. The innovative Liverpool Mission, as has not previously been noticed, emerged from the wider home mission movement.

The paid lay agents employed by Garrett were something of a novelty in this period. The Wesleyan system, of course, depended on lay preaching, but only rarely in the past had lay preachers been hired for specific duties. It was hoped when the regulations for home mission ministers were drawn up that they would be able to recruit 'pious and earnest Members of Society' to assist as volunteers. ${ }^{62}$ That happened on a large scale in some places. At Pitt Street, Liverpool, in the early balmy days of the mission, the agent 'succeeded in engaging probably not less than one hundred lively and active Christians, male and female, who cheerfully co-operate with him'. ${ }^{63}$ Again, in the late 1870 s it became fashionable to organise mission bands of young men who would go out into the streets to invite strangers to evangelistic services. ${ }^{64}$ But this type of voluntary activity was little different from what had been normal among vigorous Methodist society members in the past. What was new in the period was the systematic encouragement of engaging paid laymen to undertake missionary responsibilities. Some circuits, taking hints from the governing Conference that it was a way of obtaining inexpensive ministerial support, appointed hired lay preachers in the early 1850s. The later popular minister Peter Mackenzie was first enlisted in this way when he was a Durham miner. ${ }^{65}$ By the 1870 s there were far more of them. A survey commissioned by 
Conference in 1876 discovered 175 such paid agents. ${ }^{66}$ Two years later Conference officially commended the example of the Liverpool Mission, together with its Manchester with Salford and London equivalents, in employing lay missionaries. ${ }^{67}$ Paying lay agents was a technique of evangelistic work that grew during the period.

There was an even more significant change in the role of women in home mission. They remained active as class leaders, though rarely having men under their leadership, and it has been shown that a few Wesleyan women continued to preach after mid-century. ${ }^{68}$ There was a marked upward trend in the proportion of Sunday school teachers who were female. ${ }^{69}$ The titans of work with children, such as Hannah Frost at Lincoln Fields Wesleyan Methodist Sunday School in Leeds, the teacher of a senior class and leader of the meeting for mothers of scholars, tended to be women. ${ }^{70}$ But the most drastic alteration in the role of women was in their appointment as deaconesses. The initiative had been taken in the Church of England by William Pennefather, an Evangelical clergyman, who in 1860 opened a training home for women workers that was in 1864 transferred to his new parish of Mildmay Park in north London. Wearing special uniforms, they undertook nursing and social care as well as houseto-house visitation..$^{71}$ That was the inspiration for the employment of similar deaconesses by the Metropolitan Methodist Lay Mission, founded in about 1871 by a group including T. B. Smithies, an energetic editor of a variety of Christian journals and from 1870 a member of the Wesleyan Home Mission Committee. Wary of criticism that the venture was aping Catholic sisterhoods, the Metropolitan Mission insisted that it used the term 'deaconesses' because it was 'scriptural, Protestant, simple and descriptive'. ${ }^{72}$ Thomas Bowman Stephenson, who as a minister in Bolton had a deaconess serve in his church in 1868, determined to use more women in that capacity in the children's home he founded in London in the following year. By 1875 he had two deaconesses on the staff as matrons and was training seven more young women alongside young men. From 1878 or 1879 onwards they were called 'Sisters of the Children' and some were engaging in evangelistic work as well as 
care for the young. These developments were not officially sponsored by the Home Mission Committee, which Stephenson joined only in 1878, but eventually, in 1890, Stephenson was to establish a Wesley Deaconess Order that became the established avenue for women's ministry within the denomination. ${ }^{73}$ Long before that, however, some Wesleyan women were playing a part in Christian service with an unprecedented degree of formal recognition.

Children also became involved in home mission activities, though as supporters rather than as agents. Money-raising for home mission changed drastically during the period. At its opening the practice was normally to hold an annual collection each July to complement subscriptions from wealthier members. Prest fostered additional public meetings with visiting speakers, and that did increase the sums raised, though, if Leeds Brunswick Chapel was typical, only marginally. There in 1863 a mere $£ 11$ of the total of $£ 72$ raised for the Home Missionary and Contingent Fund came from the public meeting, even though the speaker was M'Aulay. ${ }^{74}$ The revolution in giving came when circuits adopted what was called 'the Blake system'. Joseph Blake, a draper of Harrow, had set about training the children of his neighbourhood to collect systematically for overseas mission. His 'juvenile associations' were officially adopted by the connexion in 1841 and widely publicised through Blake's booklet, The day of small things: or, incitement to juvenile activity and usefulness, founded on practical effort, in connection with Christian missions (1849). ${ }^{75}$ At first, as the title suggests, the associations were concerned solely with overseas mission, but a second edition in 1865 was issued as a guide to the formation of children's groups that would support home as well as foreign work. ${ }^{76}$ Mission at home standardly received half the amounts collected. In 1861-62 only 27 local associations contributed to the fund; by 1870-71 as many as 268 did so; and the number continued to grow. ${ }^{77}$ The spirit of competition roused children, usually organised through Sunday schools, to prodigious efforts. At Milford Haven in 1883, for instance, Annie L. Thomas won an illuminated card for collecting the biggest sum during the year, $£ 2.2 \mathrm{~s} .6 \mathrm{~d}$, and Louie Carter received a book for making the largest number of payments 
to the secretary, $43 .^{78}$ The money raised by the juvenile associations often exceeded the combined sums from other methods of collection. ${ }^{79}$ Children became the mainstay of home missionary finance. It was an ingenious way of slipstreaming the huge success of the Sunday schools of the period.

Another way in which mission was transformed was through the adaptation of the revival tradition. Methodism had thrived on spontaneous revivals, episodes of spiritual excitement when many would first embrace personal faith. They still took place from time to time during the period. In 1869 there was a 'gracious awakening' at Eastbourne, ${ }^{80}$ and two years later there was something similar at Hunmanby in the North Riding of Yorkshire. 'Without any extraneous aid our people have been quickened', the home missionary minister reported, '... and for a month in which we have held numerous services we have seldom met without witnessing the power of God unto salvation manifested in our midst. ${ }^{81}$ Membership there mushroomed from 92 to 150 . Yet Wesleyan leaders were usually wary of revivals. In 1860, the year after large-scale revival gripped much of Scotland and Wales, Samuel Waddy as president warned about the damage caused by the revival spirit. ${ }^{82}$ Revival was a force that disrupted the steady growth that the promoters of home mission preferred. It is true that M'Aulay was better disposed towards traditional revivals than many other ministers, but in 1878 he noted that over recent years there had been none in the south-east of England. ${ }^{83}$ Traditional awakenings were fading. Planned mission services, however, were becoming more common. Normally spread over weekday evenings for seven days or a fortnight, they aimed directly for conversions. 'At the close of each night's service', according to the missionary minister in Bethnal Green in 1870, 'I conversed with those who professed "repentance toward God, and faith in our Lord Jesus Christ," took down their addresses, and appointed them to classes. ${ }^{84}$ All was decent and in order. Well organised events of this kind multiplied. The visit of Moody and Sankey in 1873-75 enhanced their popularity. In 1876 mission services of the Moody kind took place in the principal chapel of each of the London 
circuits. ${ }^{85}$ 'Revival missions' became commonplace. At Blackwell in Derbyshire, for example, in April 1877 there was a week of special services led by several laymen followed by three weeks of preaching by another layman from Newcastle-upon-Tyne. ${ }^{86}$ Semiprofessional evangelists of this kind were emerging, travelling the country to conduct special services. Old-style spontaneous revivals all but disappeared in England, but they were replaced by carefully pre-planned missions.

A further novel development was the merger of evangelism with temperance. The temperance cause, the movement that from around 1830 discouraged the drinking of spirits and increasingly the taking of any alcohol, was originally separate from the churches. Although the Primitive Methodists rapidly became favourably disposed, the Wesleyan authorities under Bunting remained sceptical, seeing the campaign as a form of self-salvation that constituted an alternative to the gospel. In 1872, James Loutit, a retired minister, was still writing disparagingly of the 'rabid tee-totalers' ${ }^{87}$ Yet temperance sentiment gradually made headway in the denomination. Charles Garrett, who had signed the pledge to abstain from alcohol when he was only fifteen, was one of its leading advocates, helping in 1868 to set up The Methodist Temperance Magazine. ${ }^{88}$ The cause began to find a place in the home mission repertoire. At Chequer Alley in central London in 1870 there was a special gathering to promote temperance; and at the Green Street Mission in Bethnal Green in 1873 regular temperance meetings were held on Saturday evenings. ${ }^{89}$ Conference took up the issue in that year, appointing a Temperance Committee for the first time. Its recommendations led two years later to the creation of a Wesleyan Temperance Society, though it was open to moderate drinkers as well as total abstainers, and to official endorsement of the creation of Bands of Hope where children could be taught abstinence principles. Bands of Hope soon sprang up in home mission areas and by 1879 there were over 1,500 connected to Wesleyan Sunday schools. ${ }^{90}$ In the early 1880 s the connexion was swept by enthusiasm for the gospel temperance movement coming from America. Its members wore a blue ribbon to show that 
they had taken the total abstinence pledge. The Wesleyan children's home mission magazine for January 1884 contained an anecdote illustrating the extent to which gospel temperance had entered the denominational psyche. A little boy came home wearing a blue ribbon, persuaded his father to attend a meeting, the father duly signed the pledge and he 'now sought saving grace'. ${ }^{91}$ The pledge was evidently as much of a triumph as the conversion that had not yet taken place. Temperance, which had once been shunned, became a major feature of missionary methods.

A more deliberate innovation than the drift into organised missions and gospel temperance was the setting up of chaplaincy services for the armed forces. Religious provision in the army was essentially Anglican, though special arrangements were made for Scottish Presbyterians and separate facilities were tolerated for Roman Catholics. Charles Prest, whose natural spirit, according to his biographer, was 'martial', threw himself into demanding equal treatment for Wesleyans. ${ }^{92}$ The start of his time as secretary of the Home Mission and Contingent Fund coincided with the creation, in the aftermath of the Crimean War, of a vast military training camp at Aldershot. On 10 July 1857, a new Wesleyan iron chapel was opened close to the cavalry barracks even before they were occupied. ${ }^{93}$ William Harris Rule, a redoubtable senior minister with experience from the 1830s of nine years' service in Gibraltar, was appointed the superintendent under the auspices of the Home Mission Committee. As in Gibraltar, but this time with the backing of Prest, Rule demanded the right of Wesleyan soldiers to follow their own consciences. 'It cannot be right', wrote Prest, 'they should be marched to the Anglican or Scottish Churches, and even to the Romish Mass, as not unfrequently happened, while the Queen's regulations promise every soldier that he shall be at perfect liberty to worship Almighty God according to the forms of his own religion'. ${ }^{94}$ There ensued a protracted struggle against dogged resistance from the local chaplains and the Chaplain-General entailing correspondence with the War Office, conflict over who should conduct burials, access to hospitals for Wesleyan ministers and much else. 
Eventually, in 1862, the government announced that there would be a category in the armed services of 'Other Protestants', which conceded the central principle for which Rule and Prest had fought. ${ }^{95}$ By 1873 the Wesleyans were maintaining 11 chaplains for the army and navy in the British Isles. ${ }^{96}$ The battle against 'the ancient prejudices and customs of the army', as Prest put it, had important implications. ${ }^{97}$ To demand equal treatment for Wesleyan soldiers was to oppose Anglican exclusiveness. That meant claiming the status of a national faith, something that has been seen as distinctive to Hugh Price Hughes's later vision of Methodism. ${ }^{98}$ Such an idea, however, was already there in Prest's mind. The new stance also meant turning away from Bunting's alignment of Methodism as a sympathetic partner of the Church of England. The home mission policy on military chaplaincy made Methodism more a challenger of the established church than its coadjutor.

The experience of the home missionary ministers in the countryside was to have a similar effect. Despite Prest's urban priorities, rural mission remained close to his heart. That was entirely reasonable in the 1850s and 1860s because the population of the countryside was still growing. Rural depopulation became a significant process only from the 1870 s, though subsequently it gathered impetus. Prest addressed the relative claims of town and countryside in his report for 1859. Home mission ministers were in demand for the large towns, where work might make the most favourable impression. But not all effort should be channeled that way. 'Methodism', he continued, 'by its organisation and working, is well adapted not only to pervade the masses, but especially the scattered portions of our population; and to have confined this renewed missionary effort altogether, or principally, to the large towns, would have been a departure from the successful precedents of our history. ${ }^{, 99}$ The itinerancy, that is to say, could reach where other church systems could not. Accordingly three appointments would be made to market towns and three to country areas. Some rural circuits, after all, were in desperate need. Kington, in Herefordshire, for instance, was reportedly feebler in 1856 than it had been twenty years earlier. Because there were too few ministers, visits to the 
remote parts of a large area were infrequent. Although some urged the opening of ministry in the market town of Bishop's Castle, it was twenty-seven miles from the circuit centre and so to launch work there would be hopeless. ${ }^{100}$ It was to cater for such circumstances that the committee made grants for rural missionary ministers.

The Home Mission Committee, however, did not simply accept the existing itinerancy system. In 1865 Prest began a sustained critique of the existing methods of rural ministry. Ministers were habitually stationed in towns, making forays into the countryside to preach. Whereas in the past they would have gone on a round, staying for a few days in each village and undertaking visitation, they had increasingly adopted the practice of returning home immediately after preaching in a rural chapel. They were not getting to know the people. 'Occasional irradiation for a few hours from a central town', Prest concluded, was a discredited policy. ${ }^{101}$ The remedy, he believed at first, was forming groups of villages into rural circuits with resident ministers. ${ }^{102}$ In 1873 Prest's friend Frederick Jobson, who had served on the Home Mission Committee from its inception, wrote a pamphlet calling for fresh ventures along these lines. ${ }^{103}$ A special meeting of the committee resolved in the following year in favour of additional rural ministers, village circuits and a few ministers to concentrate on areas where Methodism was absent or languishing. ${ }^{104}$ It was the last proposal that became permanent when the 1875 Conference for the first time appointed District Missionaries. ${ }^{105}$ These men travelled round the circuits holding weekday mission services, effectively becoming the denominationally sponsored equivalent of the growing band of semi-professional evangelists. ${ }^{106}$ Although that was far from Prest's original idea, it was a significant addition to Wesleyan polity. It prepared the ground for a fresh category of denominational agents, the Connexional Evangelists, who were championed by M'Aulay when he succeeded Prest. Connexional Evangelists were District Missionaries writ large travelling preachers who held revival missions in any part of the country. M'Aulay had Conference approve the principle in 1880 and two years later made the first appointment, 
Thomas Cook, who was soon joined by Thomas Waugh and Edward Davidson. ${ }^{107}$ The three Connexional Evangelists were to gain a national and, in the case of Cook, an international reputation as winners of souls. Here was another development that, though it partially merged into the Forward Movement, was begun before that venture was conceived.

The focus on rural mission had a further consequence. Missionary ministers in the countryside often faced strong opposition. Occasionally it came from fellow-Evangelicals, whether high Calvinists, who objected to Methodist teaching, or so-called Plymouth Brethren, who rejected Methodist organisation. ${ }^{108}$ More often, however, it was from High Churchmen who resisted Methodist intrusion into their parishes. ${ }^{109}$ They were sometimes backed by local landlords, who might forbid their tenants to attend Methodist services. ${ }^{110}$ The most strident form of High Church antagonism came from the younger ritualist clergy who began to enter parishes in the 1860s. At West Bromwich in 1865 a newly installed priest told one parishioner that Methodist baptism was no baptism; another at Barrow-in-Furness warned the people that 'they must not go to the Methodist chapel; and if they do not come to church they will incur eternal perdition'. ${ }^{111}$ Prest, who had a stalwart Protestant's animosity towards Roman Catholicism, was alarmed by what he saw as the growth of cryptoCatholicism within the Church of England. The church, he wrote in 1867, had been 'perverted to the dissemination of destructive errors'. 'Avowed attempts', he declared in the following year, 'are being made to un-Protestantise the nation, and nothing but a revival of spiritual Protestant teaching and earnest efforts can prevent the success of this nefarious attempt of the traitors in our midst.' ${ }^{112}$ He conceived the home mission as an Evangelical antidote to the poison of Anglo-Catholic aggression. No longer was the Church of England a partner in mission. Instead it was increasingly the enemy to be resisted.

That perception, widely shared, led to a drastic re-evaluation of the Wesleyan selfimage. It had been normal for the leadership in the 1830s to agree with Edmund Grindrod, a champion of Conference policies, who told Bunting in 1837 that 'I fully believe it is our duty, 
as Wesleyans, to support the Established Church'. ${ }^{113}$ They might not need to be in the front rank against the foes of the church, but they were definitely ranged against Nonconformists. At the outset of the home mission operation in the 1850s, Prest regarded his denomination as one Evangelical body among others, whether Anglican or Nonconformist, both of which contained rivals as well as allies. He portrayed the Essex Congregational Union, for example, as unfriendly. ${ }^{114}$ Wesleyans were definitely not a section of Nonconformity. Still in the $1870 \mathrm{~s}$ many Wesleyans defined themselves as other than Nonconformists, as when one home missionary complained that his work in Lynton, Devon, was opposed by ritualists and 'some Nonconformists'. ${ }^{115}$ An entirely different usage, however, was arising. A missionary minister in Dudley referred in 1866 to his Wesleyan chapel as 'the only Nonconformist place of worship' in the area. ${ }^{116}$ Another, this time in Addiscombe, Surrey, in 1871 described the Wesleyan chapel as the first Nonconformist chapel in the place. ${ }^{117}$ And Prest himself in 1874 condemned the opposition of Romanisers to village Nonconformity, including Wesleyanism within that term. ${ }^{118}$ The rural confrontation between ritualism and Evangelicalism was turning mainstream Wesleyans into self-professed Nonconformists. The religious division in the land was no longer between establishment and Dissent with Wesleyans acting as a third party. Instead it was between church and chapel. The trajectory that propelled Wesleyans into fellowship with other Nonconformists in the Free Church Council movement of the 1890s was already well advanced during the mid-Victorian period. ${ }^{119}$ Home mission contributed significantly to the transformation of the bulk of Wesleyans into Free Churchmen. It helped change their very identity.

The home missionary strategy of Wesleyan Methodism during the mid-Victorian years therefore proved more adaptable than has been supposed. The reform crisis and the report on the religious census precipitated a new approach and the examples of others engaged in home mission and advocates of foreign mission helped mould it. The home missionary ministers appointed from 1856 embraced no new theology, did not challenge 
existing institutional structures and were still supported by wealthy laymen, so that there were important elements of continuity with what went before. Yet Charles Prest and his appointees promoted work in London and Liverpool that anticipated the methods of the later Forward Movement. Paid lay agents became more common, women began to serve as deaconesses, children were recruited as funders, spontaneous revivals gave way to organised missions and temperance became yoked with gospel work. Chaplaincy to the armed forces sprang up, and rural itinerancy was subjected to a critique that led to the appointment of District Missionaries and Connexional Evangelists. Opposition by ritualist clergy turned the Church of England into an apparently hostile force and, in large measure, Wesleyans into Nonconformists. This remarkable range of transformations helped ensure that Wesleyan Methodism returned after its mid-century catastrophe to a state of healthy vigour. Its vibrancy during the period is attested by the statistics. The Wesleyans, Michael Watts has concluded, held on to their share of the rising population down to 1881 , only going into decline after that date. ${ }^{120}$ The denomination was successfully growing in the years before the Forward Movement took off in the mid-1880s. Hugh Price Hughes trumpeted the advances of that epoch, but there was a great deal of more discreet change in the earlier period. Mid-Victorian Wesleyan Methodism experienced a quiet revolution in home mission.

I should like to express my gratitude to the members of staff at the John Rylands Library, Manchester, for help with sources for this paper and to the staff of the Nazarene College, Didsbury, Manchester, for the invitation to deliver it to a seminar at the college while holding a Visiting Fellowship at the John Rylands Institute/Manchester Wesley Research Centre.

${ }^{1}$ Kenneth S. Inglis, Churches and the working classes in Victorian England, London, 1963, 85-100. 
${ }^{2}$ Henry D. Rack, 'Wesleyan Methodism, 1849-1902', in Rupert Davies et al. (eds), A history of the Methodist Church in Great Britain, 4 vols, London, 1965-88, iii.123.

${ }^{3}$ Callum G. Brown, The death of Christian Britain: understanding secularisation, 18002000, $2^{\text {nd }}$ edn, London, 2001, 149-56. Clive D. Field, 'The social structure of English Methodism: eighteenth-twentieth centuries', British Journal of Sociology xxviii (1977), 199225.

${ }^{4}$ Inglis, Churches and the working classes, 89-90.

${ }^{5}$ Christopher Oldstone-Moore, Hugh Price Hughes: founder of a new Methodism, conscience of a new Nonconformity, Cardiff, 1999.

${ }^{6}$ Methodist Times, 12 Mar. 1885, 161, quoted by Inglis, Churches and the working classes, 91.

${ }^{7}$ Inglis, Churches and the working classes, 87-8.

${ }^{8}$ Roger Standing, The Forward Movement: Evangelical pioneers of 'social Christianity', Milton Keynes, 2015, 60.

${ }^{9}$ John Munsey Turner, Wesleyan Methodism, Peterborough, 2005, 50.

${ }^{10}$ David A. Gowland, Methodist secessions: the origins of Free Methodism in three Lancashire towns: Manchester, Rochdale, Liverpool, Manchester, 1979.

${ }^{11}$ Evelyn. C. Urwin, The significance of 1849: Methodism's greatest upheaval, London, 1949, 23.

12 Thomas P. Bunting, The life of Jabez Bunting, D. D., London, 1887, 727.

${ }^{13}$ Charles Haydon to Nehemiah Curnock, 3 Apr.1853, Methodist Archives, John Rylands Library, Manchester [hereinafter cited as MAM], PLP 51.29.9.

${ }^{14}$ Bunting, Jabez Bunting, p. 727.

${ }^{15}$ Charles Prest, Fourteen letters on the home-work of Wesleyan Methodism, its sustentation and extension, London, 1856, 44. 
${ }^{16}$ Michael R. Watts, The Dissenters: volume II: the expansion of Evangelical Nonconformity, Oxford, 1995, 28.

${ }^{17}$ Report of the Wesleyan Home-Mission and Contingent Fund, for the spread of the gospel in Great Britain and Ireland, with appendix, and accounts of receipts and expenditure, London, 1856 [hereinafter cited as Report with date], 6.

${ }^{18}$ Prest, Fourteen letters, 61-3.

${ }^{19}$ Report (1860), 12.

${ }^{20}$ Thomas Farmer to Isaac Keeling, 12 Nov. 1855, MAM PLP 38.68.16. Prest, Fourteen letters, 39-40.

${ }^{21}$ Report (1856), 8; (1857), 12, 14; (1861), 14-15.

${ }^{22}$ Report (1856), 32.

${ }^{23}$ Prest, Fourteen letters, 31, 32.

${ }^{24}$ Report (1856), 5 .

${ }^{25}$ John Pritchard, Methodists and their missionary societies, 1760-1900, Farnham, Surrey, 2013, 211.

${ }^{26}$ Report (1860), 11.

${ }^{27}$ Report (1861), 31.

${ }^{28}$ Report (1872), 9.

${ }^{29}$ Prest, Fourteen letters, 59-60.

${ }^{30}$ Report (1856), 23.

${ }^{31}$ Report (1858), 10, 11, 12.

${ }^{32}$ Report (1862), 11.

${ }^{33}$ Report (1876), 27.

${ }^{34}$ Report (1877), 20.

${ }^{35}$ Report (1857), 17; (1860), 18; (1865), 15; (1872), 14; (1875), 13. 
${ }^{36}$ Report (1863), 10.

${ }^{37}$ John Wesley, The works of John Wesley: volume 10: the Methodist societies: the minutes of Conference, ed. Henry D. Rack, Nashville, Tenn., 2011, 324.

${ }^{38}$ Report (1858), 11, 10.

${ }^{39}$ David W. Bebbington, Evangelicalism in modern Britain: a history from the 1830s to the 1980s, London, 1989, ch. 1.

${ }^{40}$ Report (1861), 6.

${ }^{41}$ Adeline Waddy, The life of the Rev. Samuel D. Waddy, D.D., London, 1878, 72.

${ }^{42}$ Report (1858), 13, 8 .

${ }^{43}$ Report (1862), 11.

${ }^{44}$ Report (1857), 3; (1862), 40.

${ }^{45}$ John A. Vickers (ed.), A dictionary of Methodism in Britain and Ireland, Peterborough, $2000,215$.

${ }^{46}$ Sir Francis Lycett to Gervase Smith, 28 Dec. 1872, MAM PLP 71.18.2.

${ }^{47}$ Alexander M'Aulay to Richard Tabraham, 7 Apr. 1868, MAM PLP 71.35.32.

${ }^{48}$ Calculated from Watts, Dissenters: volume II, 682-3, 708-9.

${ }^{49}$ Report (1856), 19.

${ }^{50}$ Report (1871), 14, 15.

${ }^{51}$ London Ministers' Meeting Minutes, 1865-80, MAM MAW MS 575 (hereinafter cited as LMMM), 19 Jan. 1866.

${ }^{52}$ Report (1861), 13, 15.

${ }^{53}$ William Sampson, Rev. Alexander McAulay, the Apostle of East London, London, 1896, 18-20. Report (1861), 16.

${ }^{54}$ Report (1868), 46.

${ }^{55}$ Report (1859), 12. 
${ }^{56}$ Frederic W. Macdonald, The life of William Morley Punshon, LL.D., London, 1887, 195-9, $275-8$.

${ }^{57}$ Report (1861), 34-5.

${ }^{58}$ Report (1862), 30-1.

${ }^{59}$ Report (1874), 45.

${ }^{60}$ Roger Standing, 'Charles Garrett and the birth of the Wesleyan Central Mission

Movement', Wesley and Methodist Studies vi (2014), 89-123, at 92-4.

${ }^{61}$ Methodist Recorder obituary of Garrett (n.d.), MAM PLP 43.29.1. Report (1876), 34.

${ }^{62}$ Report (1858), 12.

${ }^{63}$ Report (1861), 34.

${ }^{64}$ LMMM, 21 Feb. 1876, 17 Feb. 1879.

${ }^{65}$ H. H. M'Cullagh, Thomas M'Cullagh: a short story of a long life, London, 1909, 66.

${ }^{66}$ Report (1876), 42.

${ }^{67}$ Report (1878), 36.

${ }^{68}$ John H. Lenton, 'Labouring for the Lord: women preachers in Wesleyan Methodism, 18021932: a revisionist view', in R. Sykes (ed.), Beyond the boundaries: preaching in the Wesleyan tradition, Oxford, 1998, 67, 71.

${ }^{69}$ Brown, Death of Christian Britain, 96-7.

${ }^{70}$ James E. Ellison, History of the Lincoln Fields Wesleyan Methodist Sunday School and society (Brunswick Circuit, Leeds), 1830-1894, Leeds, 1895, 75.

${ }^{71}$ Harriette J. Cooke, Mildmay: or the story of the first deaconess institution, $2^{\text {nd }}$ edn, London, 1893.

${ }^{72}$ William Bradfield, The life of the Reverend Thomas Bowman Stephenson, B.A., LL.D., D.D., founder of 'The Children's Home' and of the Wesley Deaconess Institute, London, 1913, 173. 
${ }^{73}$ Report (1878), 3. Bradfield, Stephenson, chs 11, 19.

${ }^{74}$ Leeds First Circuit Schedule Book, 1863-73, WYL 490, 206, West Yorkshire Joint Services Archives, Leeds.

${ }^{75}$ Joseph Blake, The day of small things: or, incitement to juvenile activity and usefulness, founded on practical effort, in connection with Christian missions, London, 1849.

${ }^{76}$ Joseph Blake, The day of small things: or, a plain guide to the formation of Juvenile Home and Foreign Missionary Associations in Sunday and day schools and private families,

Sheffield, 1865.

${ }^{77}$ Report (1872), 36.

${ }^{78}$ At home and abroad: a magazine of home and foreign missions liii (May 1883), 98.

${ }^{79}$ Report (1872), 36.

${ }^{80}$ Report (1870), 48.

${ }^{81}$ Report (1871), 46.

${ }^{82}$ Watts, Dissenters: volume II, 661.

${ }^{83}$ Report (1878), 18.

${ }^{84}$ Report (1870), 44.

${ }^{85}$ LMMM, 13 Sep. 1876, 20 Nov. 1876.

${ }^{86}$ Report (1877), 20.

${ }^{87}$ James Loutit to John E. Coulson, 7 Feb. 1872, MAM PLP 70.37.8.

${ }^{88}$ Methodist Recorder obituary of Garrett (n.d.), MAM PLP 43.29.1. George Thompson

Brake, Drink: ups and downs of Methodist attitudes to temperance, London, 1974, 15.

${ }^{89}$ Report (1870), 47; (1873), 38.

${ }^{90}$ Brake, Drink, 19-23. Reports (1877), 16; (1878), 11, 12, 14.

${ }^{91}$ At home and abroad 1xi (Jan. 1884), p. 30. 
${ }^{92}$ Frederick J. Jobson, The course fulfilled: a sermon preached in City Road Chapel, London, September $6^{\text {th }}, 1875$, on the death of the Rev. Charles Prest, General Secretary of Wesleyan Home-Missions, with a sketch of the life and services of the deceased; and a plea for the mission work he officially represented, London, [1875], 41.

${ }^{93}$ Report (1858), 21.

${ }^{94}$ Report (1858), 24.

${ }^{95}$ Owen Spencer Watkins, Soldiers and preachers too, London, 1906, chs 5 and 6.

${ }^{96}$ Report (1873), 13.

${ }^{97}$ Report (1858), p. 22.

${ }^{98}$ Oldstone-Moore, Hugh Price Hughes, spec. 137-8.

${ }^{99}$ Report (1859), 5-6.

${ }^{100}$ Report (1856), 28.

${ }^{101}$ Report (1865), 11.

${ }^{102}$ Report (1873), 10.

${ }^{103}$ Frederick J. Jobson, A plea for the spread and support of Methodism in the villages, London, [1873].

${ }^{104}$ Report (1874), 7.

${ }^{105}$ Report (1875), 12.

${ }^{106}$ Report (1876), 31-4.

${ }^{107}$ Henry T. Smart, Thomas Cook's early ministry, London, 1892, 72-4.

${ }^{108}$ Report (1861), 27; (1877), 24.

${ }^{109}$ Report (1859), 25, 27.

${ }^{110}$ Report (1872), 7.

${ }^{111}$ Report (1866), 53; (1874), 40.

${ }^{112}$ Report (1867), 5; (1868), 12. 
${ }^{113}$ Edmund Grindrod to Jabez Bunting, 26 June 1837, MAM PLP 47.16.56.

${ }^{114}$ Prest, Letters, 19.

${ }^{115}$ Report (1874), 39.

${ }^{116}$ Report (1866), 54.

${ }^{117}$ Report (1871), 43.

${ }^{118}$ Report (1874), 7.

${ }^{119}$ David W. Bebbington, The Nonconformist conscience: chapel and politics, 1870-1914, London, 1982, ch. 4.

${ }^{120}$ Michael R. Watts, The Dissenters: Volume III: the crisis and conscience of Nonconformity, Oxford, 2015, 85-6. 


\begin{abstract}
Wesleyan Methodists in Victorian Britain are supposed to have been hampered by traditional methods of mission. From the 1850s onwards, however, they launched a strategy of appointing home missionary ministers. Although Wesleyans adopted no new theology, left structures unchanged and still relied on wealthy laymen, they developed fresh work in cities, employed paid lay agents, used women more and recruited children as fundraisers. Organised missions, temperance activity and military chaplaincies bolstered their impact. District Missionaries and Connexional Evangelists were appointed and, in opposition to ritualist clergy, Wesleyans increasingly saw themselves as Nonconformists. They experienced a quiet revolution in home mission.
\end{abstract}


